\title{
Detection of EGFR mutations with mutation-specific antibodies in stage IV non-small-cell lung cancer
}

\author{
Sara Simonetti ${ }^{1}$, Miguel Angel Molina', Cristina Queralt ${ }^{2}$, Itziar de Aguirre², Clara Mayo ${ }^{1}$, Jordi Bertran-Alamillo', \\ José Javier Sanchez ${ }^{3}$, Jose Luis Gonzalez-Larriba ${ }^{4}$, Ulpiano Jimenez ${ }^{5}$, Dolores Isla ${ }^{6}$, Teresa Moran², Santiago Viteri ${ }^{1}$, \\ Carlos Camps ${ }^{7}$, Rosario Garcia-Campelo ${ }^{8}$, Bartomeu Massuti ${ }^{9}$, Susana Benlloch ${ }^{1}$, Santiago Ramon y Cajal ${ }^{1,10}$, \\ Miquel Taron ${ }^{1,2^{*}}$, Rafael Rosell ${ }^{1,2}$
}

\begin{abstract}
Background: Immunohistochemistry (IHC) with mutation-specific antibodies may be an ancillary method of detecting EGFR mutations in lung cancer patients.

Methods: EGFR mutation status was analyzed by DNA assays, and compared with $1 \mathrm{HC}$ results in five non-small-cell lung cancer (NSCLC) cell lines and tumor samples from 78 stage IV NSCLC patients.

Results: IHC correctly identified del 19 in the H1650 and PC9 cell lines, L858R in H1975, and wild-type EGFR in H460 and A549, as well as wild-type EGFR in tumor samples from 22 patients. IHC with the mAb against EGFR with del 19 was highly positive for the protein in all 17 patients with a 15-bp (ELREA) deletion in exon 19, whereas in patients with other deletions, IHC was weakly positive in 3 cases and negative in 9 cases. IHC with the mAb against the L858R mutation showed high positivity for the protein in 25/27 (93\%) patients with exon 21 EGFR mutations (all with L858R) but did not identify the L861Q mutation in the remaining two patients.
\end{abstract}

Conclusions: $I H C$ with mutation-specific mAbs against EGFR is a promising method for detecting EGFR mutations in NSCLC patients. However these mAbs should be validated with additional studies to clarify their possible role in routine clinical practice for screening EGFR mutations in NSCLC patients.

\section{Background}

Non-small-cell lung cancer (NSCLC) is one of the most frequent human malignancies, constituting about $80 \%$ of all lung tumors. NSCLC can be divided into genetic subsets on the basis of the activating mutations that they harbor; each of these subsets may correspond to patient cohorts that are likely to benefit from treatment with specific inhibitors [1].

Activating mutations in the epidermal growth factor receptor (EGFR), affecting hotspots within exons that code for the tyrosine kinase domain, can be found in $10-40 \%$ of NSCLC patients, mostly in adenocarcinomas, with the higher frequency observed in Asian patients $[1,2]$. About $50 \%$ of mutated patients harbor in-frame deletions in exon 19, (around codons 746 to 750) and $35-45 \%$ show the substitution of leucine 858 by an

\footnotetext{
* Correspondence: taron.miquel@gmail.com

'Pangaea Biotech, USP Dexeus University Institute, Barcelona, Spain

Full list of author information is available at the end of the article
}

arginine in the exon 21 . The remaining mutants are insertions in exon 20 (5\%) and uncommon substitutions spanning exons from 18 to 21 , such as L861Q [3,4].

These specific mutations are related to a higher sensitivity to the tyrosine kinase inhibitors (TKIs) erlotinib and gefitinib [4-7], whereas the EGFR T790 M mutation in exon 20 is observed in $50 \%$ of cases with acquired resistance to erlotinib and gefitinib [8] and has also been detected in $38 \%$ of patients with de novo drug resistance [9].

Molecular biology techniques, such as SARMS or direct automatic sequencing, are currently used to detect EGFR mutations in formalin-fixed, paraffinembedded tissues (FFPET). In our experience, in-frame deletions in exon 19 are detected by fragment analysis of fluorescently labeled PCR products, and L858R mutations in exon 21 by TaqMan assay. Mutations are then confirmed by direct sequencing $[10,11]$. However, the routine use of these methods in clinical laboratories is still often limited by financial and technical constraints.

\section{() Biomed Central}


Moreover, their sensitivity depends on the quality and the quantity of tumoral cells in FFPET. In a previous study, we developed a highly sensitive molecular method for detecting EGFR mutations in NSCLC samples containing as few as eight tumor cells [10].

The development of antibodies that specifically detect mutant EGFR protein by IHC would be an easy prescreening test to complement the molecular assays currently used for the assessment of EGFR mutations in NSCLC. Yu et al [12] have developed mutation-specific rabbit monoclonal antibodies $(\mathrm{mAb})$ against EGFR with the E746_A750 deletion in exon 19 or the L858R point mutation in exon 21 for IHC application (Cell Signaling Technology Inc., Danvers, MA, USA).

In the present study, these two rabbit mAbs were used to assess EGFR mutations in five NSCLC cell lines and in tumor biopsies from 78 stage IV NSCLC patients. The results were then compared with those obtained by other molecular analyses $[10,11]$.

\section{Methods}

\section{Sources of cell lines and culture}

The PC-9 lung tumor cell line was kindly provided by Roche (Basel, Switzerland); the A549 and H460 cell lines were purchased from the American Type Culture Collection. Tissue culture materials were obtained from Biological Industries (Kibbutz Beit Haemek, Israel) and Invitrogen (Paisley, Scotland, UK). H1650 and H1975 were kindly provided by Dr. Herbert Haack and Dr. Katherine Crosby (Cell Signaling Technology, Inc.). We received five slides of the $\mathrm{H} 1975$ cell line and five of the H1650 cell line with 4- $\mu$ m sections for IHC analysis from the Cell Signaling Technology laboratory.

\section{Study population and tumor pathology}

Twenty-six stage IV NSCLC patients had been seen at the USP Dexeus University Institute, and 52 had been previously screened for EGFR mutations and treated with erlotinib as part of the Spanish Lung Adenocarcinoma Data Base (SLADB) [11]. All of these 52 patients were known to have EGFR mutations, while the remaining 26 patients had not been previously screened. All patients provided written informed consent. Approval was obtained from the institutional review board and the ethics committee at each hospital. Table 1 shows patient characteristics.

Four- $\mu \mathrm{m}$ sections of the FFPET specimens were stained with $\mathrm{H} / \mathrm{E}$ and histologically examined. All samples were classified according to the 2004 WHO classification [13]: 5 undifferentiated large cell carcinomas and 3 small cell neuroendocrine carcinomas, 1 squamous cell carcinoma and 69 adenocarcinomas, of which 55 showed a single pattern and 14 presented mixed aspects. We further evaluated the adenocarcinoma subtype as
Table 1 Clinicopathological features of the patients analyzed for EGFR mutations by IHC assay

\begin{tabular}{|c|c|c|}
\hline & Patients (N & \\
\hline Characteristic & No. & $\%$ \\
\hline \multicolumn{3}{|l|}{ Age, years } \\
\hline Mean & 64 & \\
\hline Range & $36-85$ & \\
\hline \multicolumn{3}{|l|}{ Sex } \\
\hline Male & 28 & 36 \\
\hline Female & 50 & 64 \\
\hline \multicolumn{3}{|l|}{ Race } \\
\hline Caucasian & 78 & 100 \\
\hline \multicolumn{3}{|l|}{ Smoker } \\
\hline Ex-smoker & 26 & 33 \\
\hline Current smoker & 7 & 9 \\
\hline Never smoker & 45 & 58 \\
\hline \multicolumn{3}{|l|}{ Histology } \\
\hline Adenocarcinoma & 69 & 88.4 \\
\hline Large-cell carcinoma & 5 & 7.1 \\
\hline Squamous cell carcinoma & 1 & 1.4 \\
\hline Others & 3 & 4.3 \\
\hline \multicolumn{3}{|l|}{ Adenocarcinoma subtype } \\
\hline Glandular & 36 & 52.2 \\
\hline Solid & 20 & 29 \\
\hline Papillary & 6 & 8.7 \\
\hline Micropapillary & 1 & 1.4 \\
\hline BAC & 6 & 8.7 \\
\hline
\end{tabular}

follow: 36 adenocarcinomas with a glandular pattern, 20 with a solid aspect, 6 with a partial papillary differentiation, 1 with micropapillary aspects and 6 with a partial bronchioloalveolar pattern (Table 1).

\section{DNA extraction and mutation analyses}

Tumor cells (8 to 150) were captured by laser microdissection (Carl Zeiss MicroImaging GmbH, München, Germany) into $10 \mu \mathrm{L}$ of PCR buffer (Ecogen, Barcelona, Spain) plus proteinase $\mathrm{K}$ and incubated 4 hours to overnight at $60^{\circ} \mathrm{C}$. Proteinase was inactivated at $95^{\circ} \mathrm{C}$ for $10 \mathrm{~min}$, and the cell extract submitted to PCR. DNA from the cell line PC-9 was used as a mutated control for exon 19, and wt control for exons 20 and 21. DNA from the H1975 cell line was used as a wt control for exon 19, and mutated control for exons 21/20.

EGFR gene mutations in exons 19 and 21 were analyzed by our sensitive methodology as previously described [10]. Exons 19 and 21 of the EGFR gene were amplified by a nested PCR. Sequencing was performed using forward and reverse nested primers with the ABI Prism 3100 DNA Analyzer (Applied Biosystems, Foster City, CA, USA). In addition to sequencing, EGFR deletions in exon 19 were determined by length analysis of 
fluorescently labeled PCR products. The collected data were evaluated with the GeneScan Analysis Software (Applera, Norwalk, CT, USA). Finally, EGFR mutation (L858R) in exon 21 was also determined by TaqMan ${ }^{\odot}$ Assay (Applied Biosystems). The L861Q mutation was detected by direct sequencing.

\section{Immunohistochemical analysis}

The following antibodies were used for the IHC analysis (Cell Signaling Technology, Inc.): EGF Receptor (D38B1), EGFR E746-A750 deletion specific (6B6) and EGFR L858R mutant-specific (43B2). The FFPET samples were cut serially at $4 \mu \mathrm{m}$ and the sections were introduced in the stainer and automatically deparaffinized (Leica Microsystems BondMAX Automated Immunostainer, Wetzlar, Germany). The reactives were added automatically, treating the samples with EDTA buffer ( $\mathrm{pH}$ 9.0) (Bond Epitope Retrieval Solution 2, Leica Microsystems) as antigen retriever and processed for $30 \mathrm{~min}$. The slides were incubated with the antibodies against EGF receptor and EGFR mutations at a dilution of 1:100 for 60 minutes. After the sections were treated with the streptavidin-biotin-peroxidase complex method (Bond Polymer Refine Detection, Leica Microsystems) with diaminobenzidine (DAB) as a chromogen and counterstained with hematoxylin.

IHC expression of mAbs against EGFR was evaluated using the following scoring, as previously described [14]: $0=$ negative or faint staining in $<10 \%$ of tumor cells; 1 = weak staining in $>10 \%$ of cancer cells; 2 = moderate staining; 3 = strong staining. A score of 0 was considered negative, a score of 1 was considered weakly positive, and a score of 2 or 3 was considered highly positive (Additional File 1, Figure S1).

\section{Statistical analyses}

The absolute and relative frequencies of qualitative variables were calculated in percentages. The sensitivity and specificity of the EGFR test by IHC was determined in comparison with PCR-based results. All analyses were performed using SPSS v 16.0 software (SPSS Inc., Chicago, IL).

\section{Results}

\section{EGFR mutation analysis in NSCLC patients}

We screened EGFR mutations in 78 FFPET samples from NSCLC patients by a methodology described elsewhere [10], which involves fragment analysis (exon 19), Taqman assay (exon 21) and sequencing. Twenty-six samples were analyzed in the Pangaea Biotech Oncology Laboratory and 52 from a previous study [11] were analyzed in the Catalan Institute of Oncology, Hospital Germans Trias i Pujol. Twenty-two samples (28\%) were wt EGFR, 29
(37\%) had a deletion in exon 19, and 27 (35\%) had mutations in exon 21 . Of the 29 patients with the exon 19 deletion, 17 (59\%) had 15-bp deletions (16 with del E746A750 [ELREA] and 1 with del E746-A750 [ELREA] + T751I), and 12 (41\%) had rare deletions of 9-bp, 12-bp, 18-bp, 21-bp or 24-bp. Of the 27 patients with exon 21 mutations, 25 (93\%) had the L858R mutation and 2 (7\%) had the L861Q mutation (Additional File 1, Table S1).

\section{IHC analysis of mutation-specific mAbs against EGFR in human NSCLC cell lines}

We analyzed by IHC five human NSCLC cell lines with known EGFR gene status. In the two cell lines with wt EGFR (H460 and A549), we found positive (score 3) expression of EGFR (D38B1) protein (100\%) and negative (score 0) expression of EGFR E746-A750 deletion specific (6B6) and EGFR L858R mutant-specific (43B2).

In the two cell lines with exon 19 deletion (15 bp) (H1650 and PC9), expression of EGFR (D38B1) protein and EGFR E746-A750 deletion specific (6B6) was positive (score 3) (100\%) and expression of EGFR L858R mutant-specific (43B2) was negative (score 0).

The cell line H1975 with exon 21 mutation (L858R) showed positivity (score 3) for EGFR (D38B1) and EGFR L858R mutant-specific (43B2) (100\%) and negativity (score 0) for EGFR E746-A750 deletion specific (6B6). (Table 2, Figure 1).

\section{IHC analysis of mutation-specific mAbs against EGFR in NSCLC patients}

In 22 tumor tissues with wt EGFR, we found high expression of EGFR (D38B1) protein (score 2 or 3 ) in 8 cases (36\%) and weak positivity (score 1) in 4 cases (18\%). All the cases were negative for EGFR E746-A750 deletion specific (6B6) and EGFR L858R mutant-specific (43B2) proteins.

In the 29 patients with exon 19 deletions, high expression of EGFR E746-A750 deletion-specific (6B6) protein (score 2 or 3 ) was observed in $17 / 17$ cases $(100 \%)$ with 15-bp deletion (16 with ELREA and 1 with ELREA + T751I). Of the 12 cases showing uncommon deletions in exon 19 , nine $(75 \%)$ samples were completely negative (score 0 ) and $3(25 \%)$ were weakly positive (score 1). All cases were negative (score 0) for EGFR L858R mutant-specific (43B2) protein.

In the 27 patients with exon 21 mutations, IHC with the mAb against the L858R mutation showed high positivity for the protein (score 2 or 3 ) in 25/27 (93\%) and in $100 \%$ of the 25 samples with the L858R substitution; however, it failed to identify the L816Q mutation (0/ 2 cases). In addition, all 27 samples were negative for the EGFR E746-A750 deletion-specific (6B6) protein (Tables 2 and 3, Figures 2 and 3). 
Table 2 IHC expression of EGFR mutation antibodies in human NSCLC cell lines and in NSCLC tumor tissues

\begin{tabular}{|c|c|c|c|}
\hline EGFR mutation status & $\begin{array}{l}\text { EGFR (D38B1) } \\
\text { Ab (+) }\end{array}$ & $\begin{array}{c}\text { EGFR E746-A750 deletion-specific } \\
\text { (6B6) } \mathrm{Ab}(+)\end{array}$ & $\begin{array}{l}\text { EGFR L858R mutant-specific } \\
\text { (43B2) Ab (+) }\end{array}$ \\
\hline H460 and A549 (WT) & $2 / 2(100 \%)$ & $0 / 2(0 \%)$ & $0 / 2(0 \%)$ \\
\hline H1650 and PC9 (DEL 19) & $2 / 2(100 \%)$ & $2 / 2(100 \%)$ & $0 / 2(0 \%)$ \\
\hline H1975 (L858R + T790M) & $1 / 1(100 \%)$ & $0 / 1(0 \%)$ & $1 / 1(100 \%)$ \\
\hline Tumor Tissue (WT; $\mathrm{N}=22$ ) & $8 / 22(36 \%)$ & $0 / 22(0 \%)$ & $0 / 22(0 \%)$ \\
\hline Tumor Tissue (DEL 19;N = 29) & $28 / 29(97 \%)$ & $20 / 29(69 \%)$ & $0 / 29(0 \%)$ \\
\hline Tumor Tissue (MUT 21; $\mathrm{N}=27$ ) & $26 / 27(96 \%)$ & $0 / 27(0 \%)$ & $25 / 27(93 \%)$ \\
\hline
\end{tabular}

Abbreviations: WT: wild-type. DEL 19: Exon 19 deletion; MUT 21: Exon 21 mutation.

\section{Discussion}

EGFR is a member of the ErbB family of receptor tyrosine kinases, which also includes HER2/neu, HER3, and HER4 [15]. Activating mutations in the tyrosine kinase domain, involving mainly exons 19 and 21, play an important role in lung oncogenesis and tumor progression and are related to the clinical efficacy of EGFR TKIs such as gefitinib or erlotinib [5,9,11]. Analysis of these mutations has become an important tool for targeted therapy in lung cancer ${ }^{3}$, and in recent years many efforts have been made to find a more specific and sensitive methodology to detect them [10,16-18]. Nevertheless, these techniques are relatively expensive for routine use in clinical laboratories, and depend on the quality of the samples. IHC is a standardized assay of simple methodology and high sensitivity and specificity, and the development of specific antibodies against EGFR mutation proteins might be useful for the diagnosis and treatment of lung cancer.

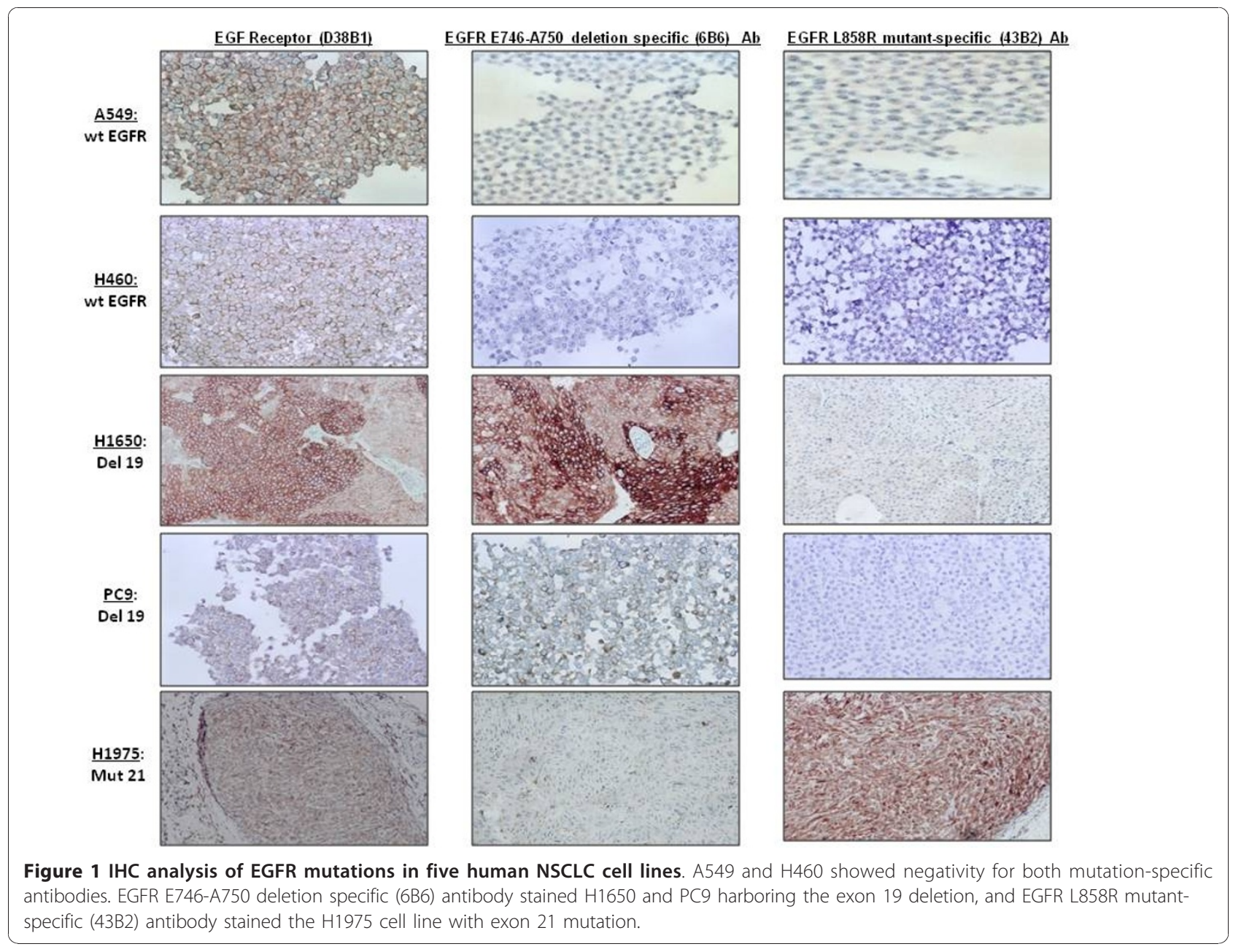


Table 3 Correlation of IHC expression of mutation-specific antibodies and EGFR exon 19 deletion subtype analyzed by GeneScan, TaqMan and direct sequencing

\begin{tabular}{|c|c|c|c|c|}
\hline EGFR EXON 19 DELETION SUBTYPE & 0 & $1+$ & $2+$ & $3+$ \\
\hline $\begin{array}{c}15 \text { bp } \\
\mathrm{N}=17\end{array}$ & $0 / 17(0 \%)$ & $0 / 17(0 \%)$ & $2 / 17(11 \%)$ & 15/17 (89\%) \\
\hline $\begin{array}{c}9 \text { bp } \\
N=4\end{array}$ & $2 / 4(50 \%)$ & $2 / 4(50 \%)$ & $0 / 4(0 \%)$ & $0 / 4(0 \%)$ \\
\hline $\begin{array}{l}12 \text { bp } \\
N=1\end{array}$ & $1 / 1(100 \%)$ & $0 / 1(0 \%)$ & $0 / 1(0 \%)$ & $0 / 1(0 \%)$ \\
\hline $\begin{array}{l}18 \mathrm{bp} \\
\mathrm{N}=5\end{array}$ & $4 / 5(80 \%)$ & $1 / 5(20 \%)$ & $0 / 5(0 \%)$ & $0 / 5(0 \%)$ \\
\hline $\begin{array}{l}21 \text { bp } \\
N=1\end{array}$ & $1 / 1(100 \%)$ & $0 / 1(0 \%)$ & $0 / 1(0 \%)$ & $0 / 1(0 \%)$ \\
\hline $\begin{array}{l}24 \text { bp } \\
N=1\end{array}$ & $1 / 1(100 \%)$ & $0 / 1(0 \%)$ & $0 / 1(0 \%)$ & $0 / 1(0 \%)$ \\
\hline
\end{tabular}

In 2009 Yu et al [12] first generated two mAbs against E746-A750del and L858R point mutation from New Zealand rabbits and evaluated them by Western blotting, immunofluorescence and IHC. They tested these antibodies in a series of cell lines and in tumor tissues from patients with primary NSCLC, with known and unknown EGFR mutations, comparing the IHC results with DNA sequencing. They found that IHC with these mutation-specific antibodies for EGFR mutations showed a sensitivity of $92 \%$ and a specificity of $99 \%$.

Recently, five studies [14,19-22] examined the presence of EGFR mutations in NSCLC by IHC using the same






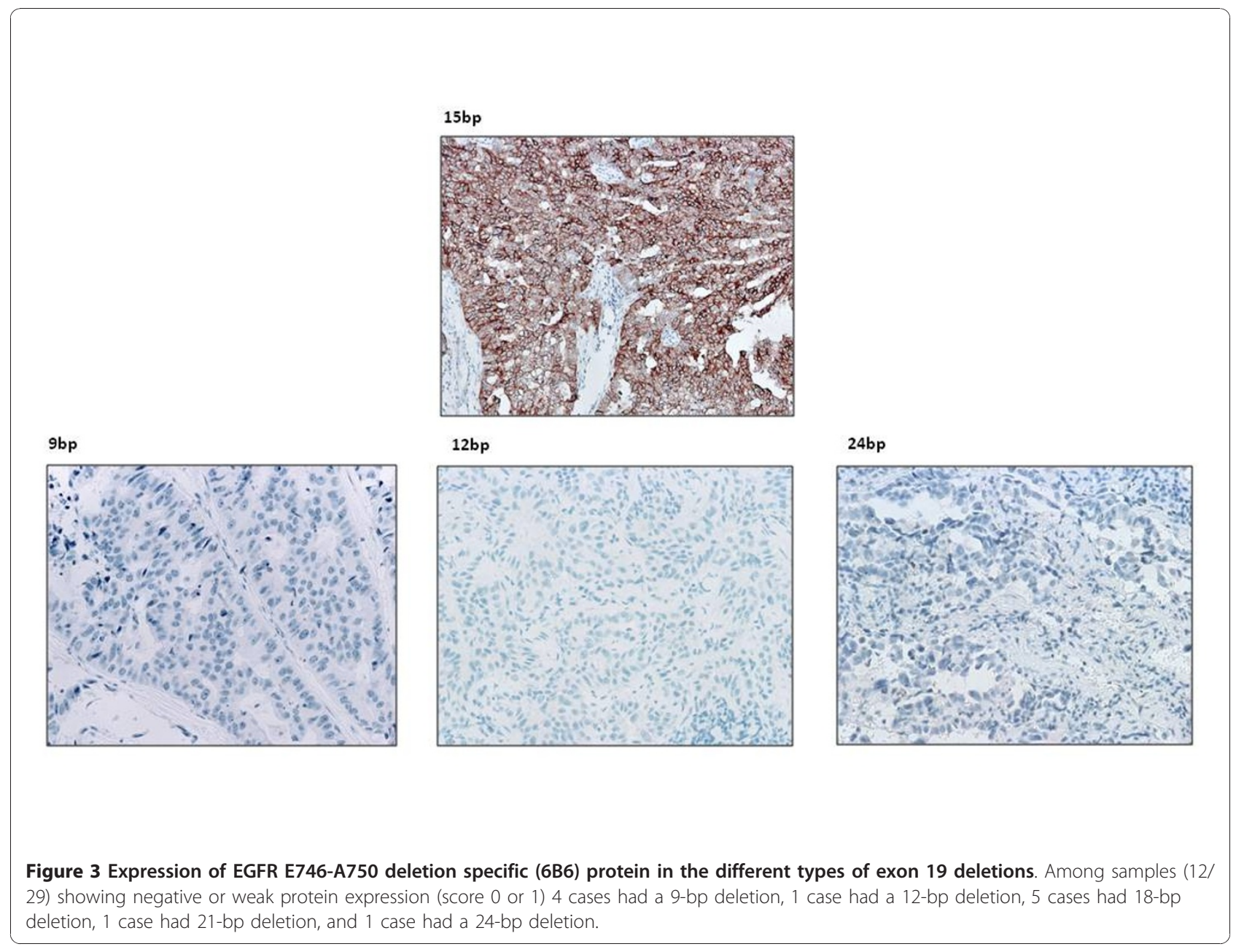

two rabbit mAbs and reported sensitivity ranging from $36 \%$ to $100 \%$ and specificity ranging from $94 \%$ to $99 \%$ (Table 4). Kato et al [20] analyzed 70 gefitinib-treated NSCLC patients. Although a high sensitivity and specificity for these mAbs were described, IHC staining was not significantly correlated with overall survival. A very exhaustive analysis of the role of EGFR in NSCLC was recently reported by Ilie et al [19]. They assessed EGFR status in a tissue microarray (TMA) of 61 lung adenocarcinomas by IHC, fluorescent in situ hybridization (FISH) and direct sequencing and compared their results with those of conventional methods performed on whole-tissue sections. The authors reported a specificity of $92 \%$ for the mAb against the E746-750 deletion. Kawahara et al [21] reported a sensitivity of $83 \%$ for the L858R mutation antibody and $79 \%$ for the exon 19 deletion antibody. Brevet et al [14] reported a sensitivity of $84.6 \%$ and a specificity of $98.9 \%$ for E746-A750 and a sensitivity of $95.2 \%$ and a specificity of $98.8 \%$ for L858R. Kitamura et al [22] reported a sensitivity of $36 \%$ and a specificity of $97 \%$ for
L858R and a sensitivity of $40 \%$ and a specificity of $99 \%$ for E746-A750. In the present study, we found a sensitivity of $100 \%$ and a specificity of $100 \%$ for the L858R exon 21 mutation antibody and a sensitivity of $63 \%$ and a specificity of $100 \%$ for the 15 -bp deletion antibody. Table 4 summarizes the clinicopathological characteristics of patients and the findings of seven studies examining EGFR mutations by IHC, including the present study.

Although the most common EGFR mutations are the 15-bp ELREA deletion in exon 19 and the L858R substitution in exon 21 [2,3], other less frequent deletions have been identified $[4,6,8,23]$. Using DNA sequencing, $\mathrm{Yu}$ et al [12] detected only two cases with uncommon deletions in exon 19; E746-T751 del stained positive and L747-A750 negative for IHC. In the present study, we had 12 samples with uncommon deletions in exon 19 (9-bp, 12-bp, 18-bp, 21-bp and 24-bp) and 2 samples with the uncommon exon 21 L816Q mutation. In these samples, IHC for both mutation-specific antibodies was not able to detect the alteration. 
Table 4 Patient characteristics and EGFR mutation status in seven studies examining EGFR mutations by IHC. (Blank cells indicate that information is not available)

\begin{tabular}{|c|c|c|c|c|c|c|c|}
\hline & Simonetti et al & Ilie et al [19] & Kato et al [20] & Kitamura et al [22] & Brevet et al [14] & Yu et al [12] & Kawahara et al [21] \\
\hline Total cases & 78 & 61 & 70 & 343 & 194 & 340 & 60 \\
\hline \multicolumn{8}{|l|}{ Age, years } \\
\hline range & $36-85$ & $42-83$ & $27-88$ & & & & \\
\hline median & 64 & 67 & 59.9 & & & & \\
\hline \multicolumn{8}{|l|}{ Sex } \\
\hline male & 28 & 31 & 36 & & & & \\
\hline female & 50 & 30 & 34 & & & & \\
\hline
\end{tabular}

Ethnicity

\begin{tabular}{|c|c|c|c|c|c|c|c|}
\hline Caucasian & 78 & 61 & 0 & 0 & & & 0 \\
\hline Asian & 0 & 0 & 70 & 343 & & & 60 \\
\hline \multicolumn{8}{|l|}{ Smoking history } \\
\hline smokers & 33 & 37 & 41 & & & & \\
\hline non-smokers & 45 & 24 & 29 & & & & \\
\hline \multicolumn{8}{|l|}{ Histology } \\
\hline adeno & 69 & 61 & 57 & & & 217 & 60 \\
\hline SCC & 1 & 0 & 7 & & & 112 & 0 \\
\hline LCC & 5 & 0 & 4 & & & 11 & 0 \\
\hline others & 3 & 0 & 2 & & & 0 & 0 \\
\hline \multicolumn{8}{|l|}{ EGFR } \\
\hline exon 19 & 29 & 10 & 18 & 21 & 55 & 58 & 21 \\
\hline exon21 & 27 & 0 & 12 & 14 & 18 & 56 & 23 \\
\hline wild-type & 22 & 51 & 29 & 296 & 145 & 167 & 16 \\
\hline
\end{tabular}

IHC sensitivity

\begin{tabular}{|c|c|c|c|c|c|c|}
\hline overall & & & & & & \\
\hline delE746-A750 Ab & $63 \%$ & $22.86 \%$ & $81.1 \%$ & $99 \%$ & $84.6 \%$ & $79 \%$ \\
\hline $1858 \mathrm{r} A \mathrm{~b}$ & $100 \%$ & & $75 \%$ & $97 \%$ & $95.2 \%$ & $83 \%$ \\
\hline \multicolumn{7}{|l|}{ IHC specificity } \\
\hline overall & & & & & & \\
\hline delE746-A750 Ab & $100 \%$ & $92 \%$ & $100 \%$ & $40 \%$ & $98.8 \%$ & \\
\hline L858R Ab & $100 \%$ & & $96.6 \%$ & $36 \%$ & $98.8 \%$ & \\
\hline
\end{tabular}

\section{Conclusions}

IHC with the mutation-specific rabbit mAbs against EGFR is a simple and standardized assay which could prove useful as a first, quick screening of NSCLC patients. However, although these antibodies seem to be quite reliable for the detection of patients carrying the most common EGFR mutations [12], they were not able to detect other EGFR gene mutations, such as 9-bp, 12bp, 18-bp, 21-bp or 24-bp deletions or the L861Q substitution [14]. In consequence, if the antibodies are to be used in clinical practice, molecular biology techniques will be needed to further analyze the IHC-negative patients. However, the generation of a refined panel of antibodies able to detect both the frequent and the uncommon EGFR exon 19 deletions and exon 21 mutations as well as the resistance mutation T790 $\mathrm{M}$ in exon
20 could lead to the universal application of IHC for detecting EGFR mutations in NSCLC patients, as part of the routine IHC work-up of lung adenocarcinomas.

\section{Additional material}

Additional file 1: Table S1. Table showing EGFR mutation status as detected by our sensitive methodology. Figure S1. Images showing scoring of $\mathrm{HC}$ staining of human NSCLC cell lines and lung cancer patient tumor tissues. A score of 0 was considered negative, a score of 1 was considered weakly positive, and a score of 2 or 3 was considered strongly positive

\section{Acknowledgements}

The authors thank Herbert Haack and Katherine Crosby (Cell Signaling Technology, Inc., Danvers, MA, USA) for providing the monoclonal antibodies used in the study and Ignacio Wistuba (Departments of Thoracic/Head and 
Neck Medical Oncology and Pathology, The University of Texas M. D. Anderson Cancer Center, Houston, TX, USA) for comments on an earlier version of the manuscript.

\section{Author details}

${ }^{1}$ Pangaea Biotech, USP Dexeus University Institute, Barcelona, Spain. ${ }^{2}$ Catalan Institute of Oncology, Hospital Germans Trias i Pujol, Badalona, Barcelona, Spain. ${ }^{3}$ Autonomous University of Madrid, Madrid, Spain. ${ }^{4}$ Hospital San Carlos, Madrid, Spain. ${ }^{5}$ Hospital La Princesa, Madrid, Spain. ${ }^{6}$ Hospital Lozano Blesa, Zaragoza, Spain. ${ }^{7}$ Hospital General de Valencia, Valencia, Spain. ${ }^{8}$ Hospital Juan Canalejo, La Coruña, Spain. ${ }^{9}$ Hospital General de Alicante, Alicante, Spain. ${ }^{10}$ Hospital Vall d'Hebron, Barcelona, Spain.

\section{Authors' contributions}

SS, MT, RR participated in the design of the study and its writing. MAM, CQ IDA, CM, JBA, SB carried out the molecular genetic studies. JLGL, UJ, DI, TM, SV, CC, RGC, BM have made substantial contributions to acquisition of data. JJS, MT, RR, SS have made substantial contributions to analysis and interpretation of data. SS, SRC carried out the immunoassays. JJS performed the statistical analysis. All authors read and approved the final manuscript.

\section{Competing interests}

The authors declare that they have no competing interests.

Received: 16 September 2010 Accepted: 18 December 2010 Published: 18 December 2010

\section{References}

1. Sharma SV, Haber DA, Settleman J: Cell line-based platforms to evaluate the therapeutic efficacy of candidate anticancer agents. Nat Rev Cancer 2010, 10:241-253.

2. Sharma SV, Bell DW, Settleman J, Haber DA: Epidermal growth factor receptor mutations in lung cancer. Nat Rev Cancer 2007, 7:169-181.

3. Kosaka T, Yatabe Y, Endoh H, Kuwano H, Takahashi T, Mitsudomi T: Mutations of the epidermal growth factor receptor gene in lung cancer: biological and clinical implications. Cancer Res 2004, 64:8919-8923.

4. Lynch TJ, Bell DW, Sordella R, Gurubhagavatula S, Okimoto RA, Brannigan BW, Harris PL, Haserlat SM, Supko JG, Haluska FG, et al: Activating mutations in the epidermal growth factor receptor underlying responsiveness of non-small-cell lung cancer to gefitinib. $N$ Engl J Med 2004, 350:2129-2139.

5. Paez JG, Janne PA, Lee JC, Tracy S, Greulich H, Gabriel S, Herman P, Kaye FJ, Lindeman N, Boggon TJ, et al: EGFR mutations in lung cancer: correlation with clinical response to gefitinib therapy. Science 2004, 304:1497-1500

6. Paz-Ares L, Soulieres D, Melezinek I, Moecks J, Keil L, Mok T, Rosell R, Klughammer B: Clinical outcomes in non-small-cell lung cancer patients with EGFR mutations: pooled analysis. J Cell Mol Med 2009, 14(1-2):51-69.

7. Marchetti A, Martella C, Felicioni L, Barassi F, Salvatore S, Chella A, Camplese PP, larussi T, Mucilli F, Mezzetti A, et al: EGFR mutations in nonsmall-cell lung cancer: analysis of a large series of cases and development of a rapid and sensitive method for diagnostic screening with potential implications on pharmacologic treatment. J Clin Oncol 2005, 23:857-865.

8. Rosell R, Moran T, Carcereny E, Quiroga V, Molina MA, Costa C, Benlloch S, Taron M: Non-small-cell lung cancer harbouring mutations in the EGFR kinase domain. Clin Transl Oncol 2010, 12:75-80.

9. Gazdar AF: Activating and resistance mutations of EGFR in non-small-cell lung cancer: role in clinical response to EGFR tyrosine kinase inhibitors. Oncogene 2009, 28(Suppl 1):S24-31.

10. Molina-Vila MA, Bertran-Alamillo J, Reguart N, Taron M, Castella E, Llatjos M, Costa C, Mayo C, Pradas A, Queralt C, et al: A sensitive method for detecting EGFR mutations in non-small cell lung cancer samples with few tumor cells. J Thorac Oncol 2008, 3:1224-1235.

11. Rosell R, Moran T, Queralt C, Porta R, Cardenal F, Camps C, Majem M, Lopez-Vivanco G, Isla D, Provencio M, et al: Screening for epidermal growth factor receptor mutations in lung cancer. N Engl J Med 2009, 361:958-967

12. Yu J, Kane S, Wu J, Benedettini E, Li D, Reeves C, Innocenti G, Wetzel R, Crosby K, Becker A, et al: Mutation-specific antibodies for the detection of
EGFR mutations in non-small-cell lung cancer. Clin Cancer Res 2009, 15:3023-3028.

13. Motoi N, Szoke J, Riely GJ, Seshan VE, Kris MG, Rusch WW, Gerald WL, Travis WD: Lung adenocarcinoma: modification of the 2004 WHO mixed subtype to include the major histologic subtype suggests correlations between papillary and micropapillary adenocarcinoma subtypes, EGFR mutations and gene expression analysis. Am J Surg Pathol 2008, 32:810-827.

14. Brevet $M$, Arcila M, Ladanyi M: Assessment of EGFR mutation status in lung adenocarcinoma by immunohistochemistry using antibodies specific to the two major forms of mutant EGFR. J Mol Diagn 2010, 12:169-176

15. Olayioye MA, Neve RM, Lane HA, Hynes NE: The ErbB signaling network: receptor heterodimerization in development and cancer. Embo J 2000, 19:3159-3167.

16. Ohnishi H, Ohtsuka K, Ooide A, Matsushima S, Goya T, Watanabe T: A simple and sensitive method for detecting major mutations within the tyrosine kinase domain of the epidermal growth factor receptor gene in non-small-cell lung carcinoma. Diagn Mol Pathol 2006, 15:101-108.

17. Uhara M, Matsuda K, Taira C, Higuchi Y, Okumura N, Yamauchi K: Simple polymerase chain reaction for the detection of mutations and deletions in the epidermal growth factor receptor gene: applications of this method for the diagnosis of non-small-cell lung cancer. Clin Chim Acta 2009, 401:68-72.

18. Yatabe $Y$, Hida T, Horio Y, Kosaka T, Takahashi T, Mitsudomi T: A rapid, sensitive assay to detect EGFR mutation in small biopsy specimens from lung cancer. J Mol Diagn 2006, 8:335-341.

19. Ilie MI, Hofman V, Bonnetaud C, Havet K, Lespinet-Fabre V, Coelle C, GavricTanga V, Venissac N, Mouroux J, Hofman P: Usefulness of tissue microarrays for assessment of protein expression, gene copy number and mutational status of EGFR in lung adenocarcinoma. Virchows Arch 2010, 457:483-495

20. Kato Y, Peled N, Wynes MW, Yoshida K, Pardo M, Mascaux C, Ohira T, Tsuboi M, Matsubayashi J, Nagao T, et al: Novel epidermal growth factor receptor mutation-specific antibodies for non-small cell lung cancer: immunohistochemistry as a possible screening method for epidermal growth factor receptor mutations. J Thorac Oncol 2010, 5:1551-1558.

21. Kawahara A, Yamamoto C, Nakashima K, Azuma K, Hattori S, Kashihara M, Aizawa H, Basaki Y, Kuwano M, Kage M, et al: Molecular diagnosis of activating EGFR mutations in non-small cell lung cancer using mutationspecific antibodies for immunohistochemical analysis. Clin Cancer Res 2010, 16:3163-3170.

22. Kitamura A, Hosoda W, Sasaki E, Mitsudomi T, Yatabe Y: Immunohistochemical detection of EGFR mutation using mutationspecific antibodies in lung cancer. Clin Cancer Res 2010, 16:3349-3355.

23. de Gunst MM, Gallegos-Ruiz MI, Giaccone G, Rodriguez JA: Functional analysis of cancer-associated EGFR mutants using a cellular assay with YFP-tagged EGFR intracellular domain. Mol Cancer 2007, 6:56.

doi:10.1186/1479-5876-8-135

Cite this article as: Simonetti et al:: Detection of EGFR mutations with mutation-specific antibodies in stage IV non-small-cell lung cancer. Journal of Translational Medicine 2010 8:135.

\section{Submit your next manuscript to BioMed Central and take full advantage of:}

- Convenient online submission

- Thorough peer review

- No space constraints or color figure charges

- Immediate publication on acceptance

- Inclusion in PubMed, CAS, Scopus and Google Scholar

- Research which is freely available for redistribution

Submit your manuscript at www.biomedcentral.com/submit
C) Biomed Central 